\title{
An Empirical Investigation of the Causality between Government Expenditure and Economic Growth in India during 1974-2010
}

\author{
Karabee Medhi \\ Assistant Professor, Department of Economics, Guwahati College, Assam, India \\ (Research scholar, Dibrugarh University, Dibrugarh, Assam, India)
}

\begin{abstract}
The role of government spending in economic growth is always an issue of debate. Various studies across the world have tried to investigate how government spending can influence the growth of an economy and found various results. While some studies found a positive impact of government spending on growth some found a negative impact. Some researchers also found that there is no significant long term relationship between public spending and growth. This paper attempts to examine the relationship between government spending and GDP growth in India using annual data for the period 1974-2010, under the framework of cointegration and vector error correction mechanism. This study shows evidence of a long run equilibrium relationship between spending and growth in India. The findings also support a unidirectional causality from expenditure to GDP and thereby validate the applicability of Wagner's law in India.
\end{abstract}

Keywords: Public expenditure, economic growth, granger causality, Wagner's law, cointegration, vector error correction model

\section{Introduction}

In less developed countries, such as India, the role of government is considerable in both scope and significance for accelerated economic growth. Along with the monetary policies of the government, the fiscal policy (especially the expenditure policy of the government) has been regarded as a very strong and influential instrument for economic growth in these countries. The most important role of government in such an economy is to generate social and economic infrastructure which can stimulate private investment ensuring better use of resources and boosting the level of growth in the economy.

India joined the club of globalised economy in the year 1991 when its economy was under severe fiscal and balance of payments crisis. With the initiation of several structural adjustment policies and the adoption of LPG policy since 1991, India's share to the global economy is getting larger. At the same time the expenditure of the Central Government of India has been rising tremendously in recent years. In order to formulate long term policy for the economic growth of the country it is important to know whether these expenditures have been productive. Especially in the era of globalization when it was expected that role of government in the economy will be substantially reduced, it is very important to recheck what role the government is playing in the overall development of the country. The present study aims to throw some light on this issue by examining empirically the long term relationship between government expenditure and economic growth in India during the period 1974-2010.

\section{Theoretical Background And Empirical Evidence}

The size of government spending and its effect on long term economic growth, and vice versa, has been an issue of sustained interest for decades. Many studies have analyzed the relationship between government expenditure and economic growth and their contribution to each other and observed different types of relationship between them . The theoretical literature has developed into several distinct views in an attempt to formalize the relationship between government expenditure and economic growth.

Adolph Wagner (1835-1917), the famous German political economist, hypothesized a functional relationship between the growth of an economy and the relative growth of its public sector activity. In 1883, he introduced a model which asserted that public expenditures are endogenous to economic development i.e. growth in economy causes public sector expenditures to expand .Wagner's work is based on empirical observations in a number of Western industrializing countries. Wagner expressively referred to this as the "Law of Increasing Extension of State Activity'. Since then it is well known as the 'Wagner Law'. Another version of Wagner Law was put forth by Wiseman and Peacock in their study of public expenditure in UK for the period 1890-1955. The main resent of the thesis is that public expenditure does not increase in a smooth and continuous manner, but in jerks or step like fashion.

Keynes(1936) and his supporters, however, raise the thought that during recession times the use of fiscal policies boosts economic activities i.e. expansionary fiscal policies, expanding public expenditures etc., 
increase community output. Keynesian economists have argued that increase in government spending can be an effective tool to stimulate aggregate demand for a stagnant economy and to bring about crowed-in effects on private sector. According to Keynesian view, government could reverse economic downturns by borrowing money from the private sector and then returning the money to the private sector through various spending programs. High levels of government consumption are likely to increase employment, profitability and investment via multiplier effects on aggregate demand. Thus, government expenditure, even a recurrent nature, can promote economic growth.

Thus Wagner's law and Keynesian hypothesis suggest two opposite directional relationship between public spending and growth of an economy. As such studying the underlying causal relationship between government spending and growth has been a sustained interest for decades. Many studies have analyzed the relationship between government expenditure and economic growth and their contribution to each other and observed different types of relationship between them.

S. Cheng Benjamin and Wei Lai T.(1997) formulated a trivariate framework to study the interrelationship between government spending, money supply and economic growth. They applied VAR methodology for their analysis and used the data of South Korea for the period 1954-94. From their study it is found that there is bidirectional causal linkage between government expenditure and economic growth along with money supply in Korea. Thus the relationship between government spending and growth is consistent with the conventional macroeconomic theory and it also supports the Wagner's Law.

Muhlis Bagdin and Hakan Cetinkas (2003) studied the causality between public spending and economic growth taking the data for Turkey over the period 1965-2000. They used Engel Granger cointegration test to test the long run relationship between public spending and GDP and found that these two variables were not cointegrated. On the basis of Granger causality test, they found that neither growth in national income had an effect on government expenditure nor public had a significant impact over the growth

Yasin M. (2003) made a study to examine the relationship between government spending and economic growth using panel data from the Sub Saharan Africa. He used neo classical production function as the basis for specifying his empirical model of the study. Government spending on capital formation, private investment, and foreign assistance for development, population growth and trade openness are explicitly specified as inputs which affect national output. Two alternative methods of estimation- fixed effect and random effect methods have been used to estimate the model. The results of both the estimation technique show that government spending on capital formation has positive effect on economic growth and it is also statistically significant at $1 \%$ level of significance. Trade openness also has a positive impact on growth at $1 \%$ level of significance. Private investment spending positively influences government spending and it is statistically significant at 5\% level in the random effects and at $10 \%$ level in the fixed effect model. Foreign development assistance and population growth are statistically insignificant in both the models. The results of the study imply that sufficient increase in government spending in capital formation in these countries will boost private investment and create a favorable environment for economic growth. The result of the impact of foreign assistance on growth is unexpected which demands further studies in this field.

.Wing Yuk (2005) made a study taking the data of United Kingdom for the period 1830 to 1993. He analyzed the causality between government spending and economic growth allowing for the effects of exports and for the presence of complex structural breaks in the data. The result of his study supported Wagner's law but it was sensitive to the sample period. It was found that GDP growth granger causes share of government spending in GDP indirectly through the share of total exports in GDP during the period of study.

P.K. Narayan et,al(2008) studied the validity of Wagner's law for the Fiji Island using cointegration methodology. They found long term association between national income and public spending. They used 5 different long run estimators to confirm the robustness of the results such as ordinary least square estimator (OLS), fully modified OLS estimator, the autoregressive distributed lag(ARDL) estimator, the dynamic OLS estimator, and the maximum likelihood estimator in order to test the impact of national income on government expenditure. All the five estimators provided almost consistent result on the impact of national income on spending. The study concludes that $1 \%$ increase in national income leads to $1.36-1.44 \%$ increase in government spending which is consistent with the Wagner's law. On the basis of granger causality test they found statistically significant long run causality from national income to government expenditure showing clear evidence in favour of Wagner's law.

Yay T. and Tastan H. (2009) tested three hypotheses namely the Wagner Hypotheses, Buchanan Wagner Hypotheses and the Tax Expenditure Hypotheses using the data from Turkey during the period 19502004. They used both Johansen and Engel Granger Cointegration tests to test the relationships between different variables. From the results of both the tests, a stable long run relationship was observed between real government expenditure and real income per capita. Bi directional relationship between these two variables was found from the results of granger causality test. As such the study supports both the Wagnerian and Keynesian Hypothesis of government expenditure. Stable long run relationship was also found between the ration of 
government expenditure to income and ration of real budget deficit to income but the result did not support the Buchanan Wagner Hypotheses because the causality runs from government expenditure to budget deficit. Real government expenditure and real government revenues are also found to be cointegrated and the result of granger causality rest supports the tax expenditure hypotheses.

Maku Olukayode E.(2009) examined the linkage between government spending and economic growth in Nigeria. He performed his empirical analysis using three variants of the Ram (1986) model. The first variant shows that private investment, government spending and consumption spending have positive but insignificant effect on economic growth. Moreover, human capital investment was found to have negative impact on the overall growth of the country. The second estimated variant of the Ram model also shows unsatisfactory result. This model concluded that private investment and government investment spending as a share of real output have significant negative impact on real GDP. On the other hand, human capital investment and government consumption spending was found to have positive but insignificant impact on lagged real GDP. Because of the non conformity of the results of these two models with theoretical expectations, the third variant of the Ram model was also estimated. This model also showed that only government spending on human capital has positive but insignificant impact on growth and all other factors were found to have negative and insignificant impact on the growth rate of real GDP.

With this background, the focus of this paper is to empirically evaluate the causal link between government spending and economic growth in India within the framework of cointegration process.

\section{Empirical Analysis and Results}

The present study has been carried out using annual data for India for the period 1974 to 2010. GDP at factor cost has been used as the indicator of economic growth and sum total of revenue and capital expenditure represents the total expenditure of the central government for a particular year. All data of total government expenditure and economic growth has been deflated to real values in order to eliminate the effect of price changes and natural logarithm of the variables is used. Thus the variables under study are LNRGDP and LNREXP which imply natural logarithm of real GDP and natural logarithm of real expenditure of Central government of India respectively. Source of data is various budget documents of government of India and data series published by Reserve Bank of India.

\subsection{Unit Root Test}

Unit root test is used to test the stationarity of variables. In order to test the presence of unit roots, and to determine the degree of differencing necessary to induce stationarity, Augmented Dickey Fuller test(ADF) based on the work of Dickey and Fuller (1979) is used. If a non stationary variable becomes stationary after differencing ${ }^{\text {' }}$ ' times, then it is said that order of integration is ${ }^{`} \mathrm{~d}^{\prime}$. The test is based on the estimate of the following regression which includes both a constant term and a trend:

$$
\Delta \mathbf{Y}_{\mathrm{t}}=\alpha_{0}+\alpha_{2} \mathbf{t}+\gamma \mathbf{Y}_{\mathrm{t}-1}+\sum_{\mathrm{i}=2}^{\mathrm{p}} \beta_{\mathrm{i}} \mathbf{Y}_{\mathrm{t}-\mathrm{i}+\mathbf{1}}+\varepsilon_{\mathrm{t}}
$$

The null hypothesis is: $\gamma=0$ i.e. the series has a unit root and is non stationary. The results of Unit root test are summarized in table 1

Table 1: Result of ADF unit root test

\begin{tabular}{|l|c|l|}
\hline In level & $1^{\text {st }}$ difference & Stationarity \\
\hline \multicolumn{3}{|c|}{ Variable: LNRGDP } \\
\hline $0.322581[0](3.540328)$ & $7.615968[0](3.544284)$ & $\mathrm{I}(1)$ \\
\hline \multicolumn{3}{|c|}{ Variable: LNREXP } \\
\hline $3.098459[1](3.544284)$ & $3.859382[3](3.557759)$ & $\mathrm{I}(1)$ \\
\hline
\end{tabular}

Lagged differences are shown in brackets and critical values for ADF statistic with constant and linear trend at 5\% level are shown in parentheses. Here lags are determined by SIC lag selection criterion. Table 1 show that absolute values of ADF statistic is more than the critical values at $5 \%$ level of significance when we take the first difference of the variables. So the null hypothesis of presence of a unit root can be rejected in case of the first differenced variables and therefore both the variables under consideration are I (1)

\subsection{Lag length test}

In order to assure consistency of the research findings with real economic situations and economic theories, appropriate lag length has been selected using VAR framework for cointegration test, VEC model and causality test. The result of lag length selection criterion is shown in table 2 . 
Table 2: Lag selection based on VAR lag length criterion

\begin{tabular}{|c|c|c|c|c|c|}
\hline Lag & $\begin{array}{c}\text { LR(Sequential } \\
\text { modified LR test } \\
\text { statistic) }\end{array}$ & $\begin{array}{c}\text { FPE(Final Prediction } \\
\text { Error) }\end{array}$ & $\begin{array}{c}\text { AIC(Akaike } \\
\text { Information } \\
\text { Criterion) }\end{array}$ & $\begin{array}{c}\text { SC(Schwarz } \\
\text { Information } \\
\text { Criterion) }\end{array}$ & $\begin{array}{c}\text { HQ(Hannan-Quinn } \\
\text { Information } \\
\text { Criterion) }\end{array}$ \\
\hline 0 & NA & 0.014459 & 1.439250 & 1.531765 & 1.469407 \\
\hline 1 & 194.3296 & $1.81 \mathrm{e}-05$ & -5.243030 & $-4.965484^{*}$ & -5.152557 \\
\hline 2 & 3.424163 & $2.07 \mathrm{e}-05$ & -5.116664 & -4.654088 & -4.965876 \\
\hline 3 & $15.83194 *$ & $1.40 \mathrm{e}-05^{*}$ & $-5.518264 *$ & -4.870657 & $-5.307160^{*}$ \\
\hline 4 & 3.188988 & $1.59 \mathrm{e}-05$ & -5.405153 & -4.572516 & -5.133734 \\
\hline 5 & 3.436993 & $1.79 \mathrm{e}-05$ & -5.318939 & -4.301270 & -4.987204 \\
\hline 6 & 3.421244 & $2.01 \mathrm{e}-05$ & -5.250943 & -4.048244 & -4.858893 \\
\hline
\end{tabular}

*indicates lag order selected by the criterion

As shown in table 2, LR, FPE, AIC and HQ criterion suggested lag length 3 while according to the SC criterion lag length should be 1 . So lag length 3 will be used for cointegration test and vector error correction model.

\subsection{Long Run Cointegration Test}

As the variables under consideration are found to be I (1), the next step is to check whether they are cointegrated. Existence of cointegration shows evidence of a long run relationship between variables and they share a common stochastic and deterministic trend and they tend to move together through time. For testing the presence of cointegration, Johansen $(1988,1955)$ full information maximum likelihood method is applied. This method is based on maximum Eigen value and trace statistics of the stochastic matrix. The results of cointegration test is shown in table 2

Table 3: Result of Johansen Cointegration Test

\begin{tabular}{|c|c|c|c|}
\hline Null Hypothesis & Test Statistic & 0.05 critical value & Probability** \\
\hline \multicolumn{4}{|c|}{ Trace statistic } \\
\hline $\mathrm{r} \leq 0^{*}$ & 22.16325 & 20.26184 & 0.0271 \\
\hline $\mathrm{r} \leq 1$ & 5.021486 & 9.164546 & 0.2811 \\
\hline \multicolumn{4}{|c|}{ Maximum Eigenvalue statistic } \\
\hline $\mathrm{r} \leq 0^{*}$ & 17.14177 & 15.89210 & 0.0317 \\
\hline $\mathrm{r} \leq 1$ & 5.021486 & 9.164546 & 0.2811 \\
\hline
\end{tabular}

*denotes rejection of the null hypothesis at $5 \%$ level of significance

**Mackinnon-Haug-Michelis(1999) p-values

Table 3 gives the results of Johansen cointegration test with 3 period lags as suggested by the lag selection criterion. The estimation of cointegartion assumes that there is no deterministic trend in the variables but they contain a constant term. According to both trace test and maximum Eigen value test there is one cointegrating equation at 5\% level of significance. It shows that there is one equilibrium long term relationships between government expenditure and GDP in India in the period of study and these two variables move together in the long run.

\subsection{Vector Error Correction and Granger Causality}

According to Engel and Granger (1987), if two variables are cointegrated, then correspondingly there always exists an error correction model which implies that changes in the dependent variable are a function of the level of disequilibrium in the cointegrating relationship, captured by the error correction term(ECT) as well as changes in the explanatory variables. In the present study, the VECM model consists of the following equations.

$$
\begin{aligned}
& \Delta \text { LNRGDP }_{\mathrm{t}}=\gamma_{1}+\rho_{1} \mathrm{E}_{\mathrm{t}-1}++\alpha_{11} \Delta \mathrm{LNRGDP}_{\mathrm{t}-1}+\alpha_{12} \Delta \mathrm{LNRGDP}_{\mathrm{t}-2}+ \\
& \alpha_{13} \Delta \text { LNRGDP }_{t-3}+\alpha_{21} \Delta \text { LNREXP }_{t-1}+\alpha_{22} \Delta \text { LNREXP }_{t-2}+ \\
& \begin{array}{l}
\alpha_{23} \Delta \text { LNREXP }_{\mathrm{t}-3}+\varepsilon_{1 \mathrm{t}} \\
\gamma_{2}+\rho_{2} 2_{\mathrm{t}-1}++\beta_{11} \Delta \mathrm{LNREXP}_{\mathrm{t}-1}+\beta_{12} \Delta \mathrm{LNREXP}_{\mathrm{t}-2}+
\end{array} \\
& \beta_{13} \Delta \text { LNREXP }_{t-3}+\beta_{21} \Delta \text { LNRGDP }_{t-1}+\beta_{22} \Delta \text { LNRGDP }_{t-2}+ \\
& \beta_{23} \Delta \text { LNRGDP }_{\mathrm{t}-3}+\varepsilon_{2 \mathrm{t}}
\end{aligned}
$$

Where

$\triangle \mathrm{LNRGDP}$ and $\triangle \mathrm{LNREXP}_{\mathrm{t}}$ are first difference of GDP and Expenditure variables

$\mathrm{E} 1$ and $\mathrm{E} 2$ are the error correction terms

$\alpha_{i j}, \beta_{i j}$ are short run coefficients ( $\mathrm{i}=1,2,3$ and $\left.\mathrm{j}=1,2,3\right)$ 
and $\varepsilon_{1 \mathrm{t}}$ and $\varepsilon_{2 \mathrm{t}}$ are residuals

The error correction term in each of the equations is the lagged value of residuals derived from the cointegrating regression of the explanatory variables on the dependent variable. It measures the speed of adjustment from short run deviations towards the long term equilibrium relationship or to the long run steady path. According to Granger $(1969 ; 1988)$, in a cointegrated system of two series expressed by error correction representation, causality must run in at least one way. Within the ECM formulation of equations (2) and (3), expenditure does not granger cause GDP if $\alpha_{21}=\alpha_{22}=\alpha_{23}=0$ and GDP does not granger cause government expenditure if $\beta_{21}=\beta_{22}=\beta_{23}=0$. The result of VEC model is shown in table 4

Table 4: Result of Vector Error Correction Model

\begin{tabular}{|c|c|c|c|c|c|}
\hline Dependent variable & Independent variable & Coefficient & Std. Error & t-Statistic & Prob. \\
\hline \multirow{8}{*}{$\Delta$ LNRGDP $_{\mathrm{t}}$} & $* \mathrm{E} 1_{\mathrm{t}-1}$ & -0.007181 & 0.003185 & -2.254918 & 0.0285 \\
\hline & $\Delta$ LNRGDP $_{\mathrm{t}-1}$ & -0.110856 & 0.191785 & -0.578024 & 0.5658 \\
\hline & $\Delta$ LNRGDP $_{\mathrm{t}-2}$ & -0.153525 & 0.191041 & -0.803626 & 0.4254 \\
\hline & $\Delta$ LNRGDP $_{\mathrm{t}-3}$ & 0.146418 & 0.230352 & 0.635629 & 0.5279 \\
\hline & $\Delta$ LNREXP $_{\mathrm{t}-1}$ & -0.028997 & 0.025224 & -1.149578 & 0.2558 \\
\hline & $\Delta$ LNREXP $_{\mathrm{t}-2}$ & -0.038754 & 0.024285 & -1.595788 & 0.1168 \\
\hline & $\Delta$ LNREXP $_{\mathrm{t}-3}$ & -0.015552 & 0.021587 & -0.720432 & 0.4746 \\
\hline & $* \gamma_{1}$ & 0.069060 & 0.024428 & 2.827118 & 0.0067 \\
\hline \multirow{8}{*}{$\Delta$ LNREXP $_{\mathrm{t}}$} & $* \mathrm{E} 2{ }_{\mathrm{t}-1}$ & -0.205986 & 0.099121 & -2.078133 & 0.0481 \\
\hline & $\Delta$ LNRGDP $_{\mathrm{t}-1}$ & 1.106127 & 1.326332 & 0.833974 & 0.4122 \\
\hline & $* \Delta$ LNRGDP $_{\mathrm{t}-2}$ & 5.669321 & 1.321189 & 4.291075 & 0.0002 \\
\hline & $\Delta$ LNRGDP $_{\mathrm{t}-3}$ & 0.435471 & 1.593051 & 0.273357 & 0.7868 \\
\hline & $\Delta$ LNREXP $_{\mathrm{t}-1}$ & -0.358691 & 0.174445 & -2.056188 & 0.0503 \\
\hline & $\Delta$ LNREXP $_{\mathrm{t}-2}$ & -0.109156 & 0.167950 & -0.649933 & 0.5217 \\
\hline & $\Delta$ LNREXP $_{\mathrm{t}-3}$ & -0.165211 & 0.149291 & -1.106638 & 0.2790 \\
\hline & $\gamma_{2}$ & -0.295618 & 0.168935 & -1.749885 & 0.0924 \\
\hline
\end{tabular}

In the table 4 it is observed that the coefficient of the error correction term of the GDP variable is significant and negative. Its significance implies that any short run shock transmitted through the channel of GDP significantly affect the cointegrating relationship between GDP and expenditure. The negative sign of the ECT coefficient implies that the GDP series cannot drift far apart from the steady path and in the long run there is convergence towards the equilibrium path. The speed of adjustment of the error correction term is -0.007181 which is of quite small magnitude. This implies that adjustment towards the long run steady path is too weak. Only $0.7 \%$ of disequilibrium of GDP from the long run equilibrium is corrected within one year. The coefficient of the error correction term of the Expenditure variable is also negative and significant. The value of the coefficient of the ECT is -0.205986 which implies that $20 \%$ of disequilibrium in the growth path of expenditure is corrected within the current year. Thus significance of both the error correction terms also suggests that there is bi directional long run causality between GDP and expenditure.

To investigate the short run granger causality, Wald test has been conducted based on the estimated equations of the VEC model and the result is shown in table 5

Table 5: Result of Causality Test

\begin{tabular}{|l|l|l|l|}
\hline Null Hypothesis & & Value & Probability \\
\hline $\mathrm{H}_{0} 1: \beta_{21}=\beta_{22}=\beta_{23}=0$ & F test & 6.561949 & 0.0020 \\
\cline { 2 - 4 } GDP does not granger cause expenditure & $\lambda^{2}$ & 19.68585 & 0.002 \\
\hline $\mathrm{H}_{0} 2: \alpha_{21}=\alpha_{22}=\alpha_{23}=0$ & F test & 0.912581 & 0.4490 \\
\cline { 2 - 4 } Government expenditure does not granger cause GDP & $\lambda^{2}$ & 2.737742 & 0.4339 \\
\hline
\end{tabular}

Table 5 shows that the null hypothesis $\mathrm{H}_{0} 1$ can be rejected at $5 \%$ level of significance because the $\mathrm{p}$ value for both $\mathrm{F}$ test and chi square is less than $5 \%$. the This implies there is short run granger causality running from GDP to expenditure but government expenditure failed to cause GDP in the short run because the null hypothesis $\mathrm{H}_{0} 2$ cannot be rejected even at $10 \%$ level of significance. Thus the result shows that there is unidirectional short run causality from GDP to government expenditure.

\section{Conclusion}

This paper examines the relationship between government spending and economic growth in India during the period 1974-2010. The study shows that there is a long term association between these two variables and they tend to move together in the long run. The empirical study reveals that although in the long run there is bi-directional causality between government spending and economic growth, in the short run, causality is unidirectional running from economic growth to government spending but not from spending to growth. Thus 
the study supports the evidence of Wagner's law in Indian economy but no evidence can be seen for Keynesian crowding-in hypothesis. The results follow that although government spending is increasing in India, it has failed to provide necessary impetus to improve growth over the long term which is a serious issue of concern. Rise in unproductive or unfruitful spending makes less resources available for productive expenditures and also reduce private investment. Moreover, India is known to be exposed to large scale corruption and several inefficiencies. As such high degree of transparency and accountability of government spending is very necessary for proper utilization of the funds and to achieve the desired goals. There is an urgent need to initiate expenditure reform measures to reorient spending to productive expenditure(e.g. expenditure on basic infrastructure, education, health, research and technologies) and at the same time in order to improve the quality and efficiency of the government expenditure so that overall development of the country can be accelerated.

\section{References}

[1]. B.S. Cheng, T. W.Lai, Government Spending and Economic Growth in South Korea: A VAR Approach, Journal of Economic Development,22(1), June 1997,11-24

[2]. B.Muhlis , C.Hakan,Causality between Public Expenditure and Economic Growth: The Turkish Case, Journal of Economic and Social Resaerch 6(1),2003,53-72

[3]. M. Yasin, Public Spending and Economic Growth: Empirical Investigation of Sub-Saharan Africa, Southwestern Economic Review, Vol 3,2003,59-68

[4]. W. Yuk, Government Size and Economic Growth: Time-Series evidence for the United Kingdom, Econometrics Working Paper EWP0501, University of Victoria, Department of Economics, 2005

[5]. P.K. Narayan,A. Prasad, B.Singh, A Test of Wagner's Hypothesis for the Fiji Islands, Applied Economics,40,2008,2793-2801

[6]. T. Yay, H. Tastan, Growth of Public Expenditure in Turkey during the 1950-2004 period: An Econometric Analysis, Romanian Journal of Economic Forcasting-4,2009,101-118

[7]. E. O. Maku, Does Government Spending Spur Economic Growth in Nigeria, MPRA Paper no.17491, 2009

[8]. W. Enders, Applied Econometric Time Series(Wiley,2014)

[9]. S. Devarajan, S. Vinay,H. Zou,, The Composition of Public Expenditure and Economic Growth, Journal of Monetary Economics ,37,1996,313-344.

[10]. J.S. Guesh, , Government Size and Economic Growth in Developing Countries: A political-Economy Framework, Journal of Macroeconomics 19(1),1997,175-192

[11]. L.Jong-Wha, Capital Goods Imports and Long-Run Growth Journal of Development Economics,48(1),1995,91-110.

[12]. I. Adelman, The role of Government in Economic Development, Working paper no.890, Department of Agricultural and Resource Economics and Policy, 1999

[13]. M. Rasid and S. Sadiq, The Relationship Between Government Expenditure and Poverty: A Cointegration Analysis, Romanian Journal of Fiscal Policy, Volume 1, Issue 1, July, December 2010, 29-37.

[14]. W. Saad, K. Kalakech, The nature of Government Expenditure and its Impact on Sustainable Economic Growth, Middle Eastern Finance and Economics, Issue.4,2009

[15]. T.A Knoop, Growth, Welfare, and the size of Government. Journal of Economic Inquiry 37(1),103-119.

[16]. R. Ram, Government size and Economic Growth: A new Framework and some Empirical Evidence from Cross Sectional and Time Series Data, American Economic Review, Vol. 76,1986,191-203

[17]. M.Hristo, The size of Government Expenditure and the Rate of Economic Growth in Bulgaria, Economic Alternatives, Issue1,2007

[18]. B.R Kolluri,., M.J Panik,. and M.S Waheb, Government Expenditure and Economic Growth: Evidence from G7 Countries, Applied Economics,32,2000,1059-1068. 